\title{
PENGARUH SARANA PENDIDIKAN, KOMPETENSI GURU DAN MOTIVASI SISWA TERHADAP PRESTASI BELAJAR SISWA DAERAH TERPENCIL DI SD NEGERI BOGIYATEUGI KABUPATEN DOGIYAI PAPUA
}

\author{
Enias Anou \\ Universitas Negeri Malang. JI Semarang 5 Malang 65I45 \\ Email: Enanokepsek@gmail.com
}

\begin{abstract}
Penelitian ini menitik beratkan pada sarana pendidikan, kompetensi guru dan motivasi siswa terhadap prestasi belajar siswa daerah terpencil di SD Negeri Bogiyateugi Kabupaten Dogiyai Papua. Rendahnya motivasi siswa pada pembelajaran di daerah terpencil disebabkan karena beberapa penyebab misalnya yang bersumber dari diri sendiri dan luar individu. Dari berbagai permasalahan tersebut maka diperlukan Pelatihan dan sarana. Salah satu usaha untuk meningkatkan profesionalitas guru adalah pendalaman materi pelajaran melalui pelatihan-pelatihan. Beri kesempatan kepada guru untuk mengikuti pelatihan-pelatihan tanpa beban biaya atau melengkapi sarana dan kesempatan agar guru dapat banyak membaca bukubuku materi pelajaran yang dibutuhkan guru untuk memperdalam pengetahuannya. Penelitian ini bersifat kualitatif, dengan pendekatan studi kasus. Sedangkan teknik pengumpulan data melalui wawancara, observasi, dan studi dokumentasi. Teknik analisis data dalam penelitian ini melalui tahapan reduksi data, display data, verifikasi data, dan penarikan kesimpulan. Hasil penelitian ini adalah Hasil penelitian dapat dijabarkan sesuai dengan variabel yang diteliti yaitu pengaruh sarana pendidikan, kompetensi guru dan motivasi siswa terhadap prestasi belajar siswa daerah terpencil di SD Negeri Bogiyateugi. Hasil penelitian dapat digambarkan bahwa infrastruktur serta fasilitas sekolah yang kurang memadai menyebabkan penurunan kompetensi guru yang mengakibatkan kurangnya motivasi siswa dalam proses pembelajaran
\end{abstract}

Keywords : Sarana Pendidikan, Kompetensi Guru, Motivasi Siswa Daerah Terpencil

\section{PENDAHULUAN}

Pendidikan bagi bangsa yang sedang berkembang seperti bangsa Indonesia saat ini merupakan kebutuhan mutlak yang harus dikembangkan sejalan dengan tuntunan pembangunan secara bertahap. Semakin maju kualitas pendidikan, maka semakin maju pula Negara tersebut.Tidak meratanya pendidikan juga mengakibatkan kualitas pendidikan Masyarakat Indonesia masih rendah dibandingkan dengan_negara lain. Bukan hanya kualitas pendidikan yang belum merata melainkan hal-hal yang menunjang tercapainya prestasi belajar di Indonesia seperti sarana pendidikan, serta dukungan masyarakat dan lainnya. Menurut UNESCO pada Tahun 2012 melaporkan bahwa Indonesia berada di peringkat ke-64 dari I 20 berdasarkan penilaian Education Development Index (EDI) atau Indeks Pembangunan Pendidikan.

Ini menunjukkan bahwa masih banyak permasalahn utama pada guru yang dibenahi misalnya pada kurangnya terpacu, terdorong dan tergerak secara pribadi untuk mengembangkan profesi mereka sebagai guru. Para guru umumnya masih kurang mampu menulis karya ilmiah bidang pembelajaran, menemukan teknologi sederhana dan tepat guna bidang, membuat alat peraga pembelajaran, dan atau menciptakan karya seni. Guru seperti ini lebih mementingkan gaji ketimbang memikirkan bagaimana menghasilkan atau menciptakan anak didik yang berkualitas. Ada guru yang mengatakan kepada peserta didiknya bahwa kalian tidak belajar yang penting setiap bulan gaji saya tetap di terima tanpa di potong sepersen, hal ini di katakan ketika anak didiknya kesulitan dalam belajar karena kurangnya media dan sebagainya. Hanya sedikit guru yang secara sungguh-sungguh, penuh kesadaran diri dan kontinu menjalin kesejawatan dan mengikuti pertemuan-pertemuan untuk mengembangkan profesi . 
Selain itu masalah lain yang muncul dapat dilakukan dengan pembenahan dalam fasilitas, staf pengajar, daerah terpencil, dan lain-lain harus ditempuh dengan langkah yang menyeluruh. Tidak hanya memperhatikan dari kenaikan anggaran saja, tapi semuanya harus diperhatikan. Sebab akan percuma saja jika anggaran yang diberikan tinggi tapi pencapaian pembenahan terhadap fasilitas tidak terlaksana, maka akan menimbulkan masalah. Sangat di sayangkan sumber daya manusia dan mutu pendidikan menjadi rendah. Sekolah haruslah menyediakan fasilitas belajar yang memadai dan baik agar siswa merasa nyaman dalam melaksanakan proses belajar mengajar serta agar kedepannya mampu menghasilkan pribadi yang berkualitas baik mutu, mental, dan kepribadian. Selain itu kelengkapan fasilitas belajar bagi siswa juga berguna untuk melatih kemandirian siswa dalam memperoleh bahan ajar tambahan selain dari guru pengajar ataupun buku panduan yang mereka punya.

Siswa juga bisa mengembangkan daya kreativitas dan inovatifnya melalui fasilitas fasilitas belajar yang terdapat di sekolah sehingga siswa mampu menjadi pribadi yang kreatif dan inofatif. Maka dari itu tentu sangat di harapkan agar seluruh sekolah di Indonesia memiliki fasilitas yang memadai. Tentunya harus ada campur tangan dari dinas atau pemerintah yang terkait agar pemerataan fasilitas belajar dan pemerataan pendidikan yang memadai di Indonesia dapat terlaksana dengan baik. Dan niscaya kreativitas anak bangsa bisa semakin berkembang untuk menghasilkan sesuatu yang lebih inofatif lagi bagi bangsa Indonesia. Serta dengan adanya sarana dan prasarana yang memadai bagi pengeksploran kreativitas siswa, maka siswa akan mampu menghasilkan prestasi bukan hanya di Nasional tapi juga bisa sampai di dunia Internasional bahkan mereka bisa menjadi calon - calon pemimpin bangsa yang hebat di masa depan.

Tinggi rendahnya motivasi belajar dipengaruhi oleh beberapa hal yaitu baik berupa pengajaran, kurikulum, pengaruh teman sebaya, dan kondisi internal diri siswa. Berbagai penanganan telah banyak diberikan pada siswa yang mengalami permasalahan. Namun penanganan yang diberikan belum mencapai akarnya yaitu motivasi siswa untuk belajar. Motivasi penting karena menjadi salah satu faktor penting penyebab belajar. Sardiman (2007:75) "Dalam kegiatan belajar, motivasi dapat dikatakan sebagai keseluruhan daya penggerak di dalam diri siswa yang menimbulkan kegiatan belajar, yang menjamin kelangsungan dari kegiatan belajar dan yang memberikan arah pada kegiatan belajar". Secara sederhana dapat dikatakan bahwa siswa yang tidak memiliki motivasi belajar maka tidak akan terjadi kegiatan belajar pada diri siswa tersebut.

Selain itu rendahnya motivasi siswa pada pembelajaran di daerah terpencil disebabkan karena beberapa penyebab misalnya yang bersumber dari diri sendiri yang meliputi kesehatan, tingkat kecerdasan, perhatian, motivasi, dan bakat. Sedangkan penyebab yang bersumber dari luar individu, yaitu meliputi keluarga (orang tua, suasana rumah/keluarga, keadaan ekonomi keluarga), sekolah (cara penyajian materi pelajaran oleh guru, metode pembelajaran yang digunakan oleh guru, standar pelajaran, sumber belajar, kurikulum sekolah, lingkungan sekolah, disiplin sekolah), masyarakat (media massa, teman bergaul, aktivitas peserta didik di masyarakat).

Dari berbagai permasalahan tersebut maka diperlukan Pelatihan dan sarana. Salah satu usaha untuk meningkatkan profesionalitas guru adalah pendalaman materi pelajaran melalui pelatihan-pelatihan. Beri kesempatan kepada guru untuk mengikuti pelatihan-pelatihan tanpa beban biaya atau melengkapi sarana dan kesempatan agar guru dapat banyak membaca bukubuku materi pelajaran yang dibutuhkan guru untuk memperdalam pengetahuannya.

\section{METODE}

Penelitian ini penelitian kualitatif deskriptif dalam bentuk studi kasus guna menganalisis aspek pedagogik dalam pembelajaran di SD Negeri Bogiyateugi yang bertujuan untuk mengetahui Pengaruh Sarana Pendidikan, Kompetensi Guru Dan Motivasi Siswa Terhadap 
Prestasi Belajar Siswa Daerah Terpencil di Kabupaten Dogiyai Papua. Metode penelitian yang digunakan dalam penelitian ini adalah metode survei. Menurut Mubyanto dan Suratno (2008), survey merupakan suatu cara yang utama untuk mengumpulkan data primer bila data sekunder dianggap belum cukup lengkap untuk menjawab pertanyaan. Metode ini dipilih karena sesuai dengan tujuan penelitian yang ingin dicapai, yakni untuk memperoleh informasi yang bersangkutan dengan status sekolah pada saat penelitian dilakukan.

Populasi adalah himpunan individu atau objek yang banyaknya terbatas atau tidak terbatas (Moh. Pabundu Tika,2005:24). Dalam penelitian ini yang dipilih sebagai populasi adalah siswa kelas IV, V dan VI SDN Bogiyateugi. Siswa kelas IV, V dan VI SD N Bogiyateugi dipilih sebagai subyek penelitian mengingat mereka merupakan komponen penting/ utama dalam kegiatan belajar mengajar dan apakah memiliki pengaruh dalam sarana pendidikan, kompetensi guru dan motivasi belajar terhadap prestasi belajar.

\section{HASIL DAN PEMBAHASAN}

Hasil penelitian dapat dijabarkan sesuai dengan variabel yang diteliti yaitu pengaruh sarana pendidikan, kompetensi guru dan motivasi siswa terhadap prestasi belajar siswa daerah terpencil di SD Negeri Bogiyateugi. Hasil penelitian dapat digambarkan bahwa infrastruktur atau fasilitas sekolah yang kurang memadai dengan rincian 5 Ruang Kelas Belajar (RKB) WC I unit serta buku belajar yang sangat minim menyebabkan penurunan kompetensi guru yang bertugas 4 orang Guru Honor dari tamatan SMA dan mengakibatkan kurangnya motivasi siswa disekolah itu kurang lebih 90an siswa diantaranya Kelas VI I4, siswa Kelas V 2I,Kelas IV 25 dn seterusnya dalam proses pembelajaran. Peneliti dalam penelitian ini memilih informan guru kelas SD Negeri Bogiyateugi sebanyak empat orang. Guru kelas yang menjadi informan dalam penelitian ini yakni guru kelas VI, kelas V dan kelas IV, Selain guru kelas, wawancara juga dilakukan dengan kepala sekolah sebagai sumber data pembanding sekaligus sebagai pimpinan di sekolah tersebut. Tekhnik wawancara dilakukan secara bebas sehingga informan terbuka dalam memberikan informasi yang diperlukan. Hasil wawancara menguatkan hasil wawancara sebelumnya terkait penerapan aspek pedagogi yang masih kurang.

\section{Pembahasan}

Berubahnya pola pikir masyarakat tidak terlepas dari peran para guru yang terus berusaha memberi informasi dan pemahaman kepada masyarakat tentang pentingnya pendidikan bagi masa depan anak, peran seorang guru yang bertugas di kota dan di daerah terpencil memiliki perbedaan karena beban yang di pikul oleh seorang guru yang bertugas di daerah terpencil lebih berat dari pada para guru yang bertugas di kota-kota besar, salah satu yang menjadi kendala guru yang ada di daerah terpencil yaitu kurangnya pengetahuan dan pendidikan yang di miliki oleh para orang tua sehingga kebanyakan anak yang berasal dari daerah terpencil tidak mendapatkan pendidikan atau tidak meneruskan pendidikan mereka.

Kendala lainnya yang menjadi masalah para guru yang bertugas di daerah terpencil seperti kurangnya sarana dan prasarana yang di miliki oleh sekolah sehingga memberikan kesulitan pada guru saat melangsungkan proses belajar mengajar, sedikit guru yang bertugas di daerah terpencil. Hal ini tentu menimbulkan keprihatinan yang besar bagi pendidikan di Indonesia karena para guru yang bertugas di daerah terpencil juga ada yang belum lulus SI, keadaan ini tentu sangat memprihatinkan untuk anak yang mengenyam pendidikan di daerah terpencil karena banyaknya kekurangan yang harus mereka terima. Guru memiliki peran yang sangat penting bagi siswanya seperti pendidikan nasional yang bertujuan untuk mencerdaskan kehidupan bangsa, seorang guru tuntut untuk bertugas dengan professional karena guru yang profesional tidak hanya dibutuhkan di perkotaan saja namun sekolah-seolah yang berada di daerah terpencil juga sangat membutuhkan guru yang profesional untuk membimbing, mengajar, melatih dan memberikan pengetahuan dan pengabdian kepada masyrakatsehingga arti pendidikan itu benar benar dijangkau dan dirasakan oleh anak bangsa seutuh nya. 
Guru yang profesional adalah guru yang tidak hanya mengandalkan sarana yang diberikan oleh pemerintah namun seorang guru bisa dikatakan profesional apabila guru tersebut berwibawa, kreatif, selalu memberikan motivasi kepada siswa dan masyarakat setempat, bisa menguasai kelas dan memili sikap dan sifat yang baik, sehingga guru akan dihormati dan dihargai oleh siswa dan masyarakat dimanapun guru berada karena seorang guru adalah pemberi contoh bagi siswanya sehingga siswa di harapkan bisa menjadi anak yang baik dan memiliki sopan santun.

Seorang guru bisa di katakan berhasil atau berkualitas bisa dilihat dari hasil akhir siswa, guru yang dikatakan berhasil adalah jika hasil akhir siswa baik sehingga system pembelajaran guru tersebut dikatakan baik begitupula sebaliknya jika hasil akhir yang di capai siswa kurang baik atau kurang memuaskan maka system pembelajaran guru tesebut dikatakan kurang baik, namun hasil akhir yang di capai oleh siswa adalah hasil akhir yang murni atau tidak ada kecurangan yang dilakukan oleh guru seperti memanipulasi nilai siswa atau memberikan jawaban kepada para siswa dan siswinya sehingga bisa mencapai nilai yang di inginkan. Sebagian guru bahkan masih dikatakan tidak layak untuk mengajar karena kelayakan mengajar untuk seorang guru berhubungan dengan tingkat pendidikan guru tersebut,sebab ini adalah membunuh karakter anak bangsa .

\section{KESIMPULAN}

Dapat disimpulkan bahwa dalam melakukan peningkatan kualitas pendidikan di Indonesia maka perlu melakukan peningkatan kualitas guru melalui pelatihan serta menempatkan pembagian guru secara merata. Dimana dengan guru yang berkualitas maka dapat menghasilkan sumber daya yang berkualitas pula namun dalam melakukan semua itu bukanlah hal yang mudah karena dalam melakukan pemerataan pendidikan tersebut bukanlah hal yang mudah banyak daerah-daerah terpencil yang sulit untuk dijangkau sehingga sulit untuk melakukan pemerataan meskipun bisa dilakukan namun memerlukan waktu yang cukup lama karena membutuhkan banyak hal yang perlu dipersiapkan bukan hanya itu saja sekarang ini sangatlah sedikit guru yang mau dan mapu untuk ditempatkan di daerah terpencil oleh karena itu Pemerintah harus melakukan suatu upaya untuk dapat menarik simpati dari para guru-guru muda untuk dapat mau mengikuti program tes menjadi guru di daerah terpencil sehingga pemerataan pendidikan di daerah terpencil juga dapat sama seperti dengan di daerah yang lainnya.

\section{Saran}

Pemerintah adalah ujung tombak memperbaiki sistem pendidikan yang ada, pemerintah harus melakukan pogram pemerataan pendidikan di seluruh wilayah Indonesia tanpa terkecuali. Disampin itu perlu ada peningkatan infrastruktur seperti ruang ,Kantor ,leb,ruang belajar,perumahan guru,dll demi menunjang Program pemerataan pendidikan di daerah 3T Demi memajukan sekolah-sekolah di daerah terpencil, menyalurkan tenaga didik ke daerah terpencil, dan melengkapi sarana dan prasarana di daerah tersebut. Kemudian juga mengadakan sosialisasi tentang pentingnya pendidikan untuk anak-anak.

\section{DAFTAR PUSTAKA}

Creswell John W (20I2), Educational Research. Fourth Edition, Planning, Conducting, and Evaluating Quantitative and Qualitative Research. Pearson. University of NebraskaLincoln

Hamzah B Uno, Nina Lamatenggo, (20I2). Teori Kinerja dan Pengukurannya. Bumi Aksara. Imam Wahyudi, (20I2). Mengejar Profesional Guru. Strategi praktis mewujudkan citra guru profesional. PrestasibPustaka Publisher.

Ivancevich, Matteson, Konopaske, 2008. Organizational Behavior and Management . Published by McGraw-Hill 
Hadi, Kamila, N. 20 I2. Penuhi Hak Pendidikan Anak di Daerah Pedalaman. Melalui http:// pendidikankita.com

Nazmu Laila. 2009.Yang Terdepan yang Terbelakang (www.ui.ac.id). Diakses pada 13 November 2009.

Sayogyo. 2002. Pengembangan Pedesaan. Bahan Bacaan jilid I \& 2.UGM Press Jaya 2009.Standar Sarana dan Prasarana Pendidikan (www.idionbiu.com). Diakses pada 12 November 2009 